\title{
Relationship Between Seed Yield and Shoot Ions at Vegetative and Reproductive Stages of Rapeseed Genotypes under Saline Environment
}

\author{
Valiollah Rameeh $^{1, *}$, Ali Cherati ${ }^{1}$, Farid Abbaszadeh ${ }^{2}$ \\ ${ }^{1}$ Agricultural and Natural Resources Research Center of Mazandran, Sari, Iran \\ ${ }^{2}$ Former graduate of M. Sc
}

\begin{abstract}
Soil salinity is a major constraint to crop production in many areas of the world. To investigate the effects of salinity stress on seed yield and shoot ions at vegetative and reproductive stages, a factorial experiment was applied for evaluating the seven rapeseed genotypes under four salinity levels including $0,4,8$ and $12 \mathrm{dsm}^{-1}$. The salt solution was prepared by taking $\mathrm{NaCl}: \mathrm{CaCl}_{2}$ in the ratio of 1:1. Significant mean square of salinity levels were exhibited for seed yield and all shoot ions at two growth stages except $\mathrm{Ca}$ at reproductive stage. Due to increasing salinity levels $\mathrm{Ca}$ at vegetative stage was increased in L14 and Zarfam but in other genotypes it was not affected by increasing salinity levels. Significant negative correlation of $\mathrm{K}$ with $\mathrm{Na}$ and $\mathrm{Cl}$ indicating the ameliorating effect of $\mathrm{K}$ on toxic effects of $\mathrm{Na}$ and $\mathrm{Cl}$. Due to adverse effect of $\mathrm{Cl}$ on seed yield, the correlation of this ion with seed yield was significant and negative at vegetative and reproductive stages. Significant positive correlation of $\mathrm{K}$ content at vegetative stage with seed yield implied that $\mathrm{K}$ at this stage can be used as selection criterion for detecting high seed yield genotypes in saline environment.
\end{abstract}

Keywords Factorial Experiment, Rapeseed, Salinity, Shoot Ions, Reproductive Stages

\section{Introduction}

Soil salinity greatly decreases the productivity of economically important plants such as Brassica specious. Saline environments affect the plant growth in different ways such as reduction water uptake, an accretion of ions to toxic levels, and a reduction of nutrient accessibility. Two primary lines of action were emphasized for decreasing salinity effects on crop production: reclamation of salt-affected soils by chemical amendments, and alternatively, the saline soils can be used to grow salt-tolerant plants[2]. High salt stress disrupts homeostasis in water potential and ion distribution. This disruption of homeostasis occurs at both the cellular and the whole plant levels[24]. Tolerance of oilseed brassicas to salt stress is a complex trait, which is greatly modified by environmental conditions such as cultural, climatic and biological factors $[13,15,16]$. High salt concentration in root affects the growth and yield of many important crops. The salinity may reduce the crop yield by disturbing water and nutritional balance of plant[7,11]. Water accessibility and nutrient uptake by plant roots is limited because of high osmotic potential and toxicity of sodium $(\mathrm{Na})$ and chlorine

* Corresponding author:

valvandi225@yahoo.com (Valiollah Rameeh)

Published online at http://journal.sapub.org/plant

Copyright (C) 2012 Scientific \& Academic Publishing. All Rights Reserved
(Cl) ions[13]. Saline soils and saline irrigation waters present potential hazards to canola production. The most common undesirable effect of salinity on the crop of Brassica is the reduction in plant height, size and yield as well as deterioration of the product quality[26]. There are differences in sensitivity to salinity among canola cultivars[15,19]. Calcium $(\mathrm{Ca})$ and potassium $(\mathrm{K})$ ameliorate the adverse effects of salinity on plants $[1,17,25]$. Salinity impairs the uptake up Ca by plants, possibly by displacing it from the cell membrane or in some way affecting membrane function[14,20]. Gorham[8] claimed that all plants discriminate to some extent between $\mathrm{Na}$ and $\mathrm{K}$. Na can be substituted for $\mathrm{K}$ for uptake, and it is believed that similar mechanisms of uptake may operate for both ions[10,18,21]. High levels of $\mathrm{K}$ in young expanding tissue is associated with salt tolerance in many plant species[2,3,17]. Closely allied to salt exclusion and its relationship to salt tolerance is the regulation of ion selectivity, in particular the role of $\mathrm{Ca} / \mathrm{Na}$ and $\mathrm{K} / \mathrm{Na}$ discrimination in salt tolerance[22,25]. He and Cramer[10] reported that $\mathrm{Ca}$ could play a regulatory role in the responses of Brassica species to saline environments. Thakral et al.[23] reported positive non-significant correlation between seed yield and $\mathrm{K} / \mathrm{Na}$ in stress environment in $B$. juncea. These researchers also pointed out that in response to increasing salt stress $\mathrm{K} / \mathrm{Na}$ decreased while chlorophyll, proline and protein contents increased. Das et al.[6] claimed that increase in $\mathrm{NaCl}$ concentration was associated with increased $\mathrm{Na}$ and 
$\mathrm{Cl}$ influx and $\mathrm{K}$ efflux in B. campestris.

The objective of the present study was to investigate the effect of salinity on the yield and shoots ions at vegetative and reproductive stages and their relation to seed yield in order to obtain suitable criteria for salinity tolerance.

\section{Materials and Methods}

Seven diverse rapeseed genotypes including three breeding lines $\left(\mathrm{L}_{14}, \mathrm{~L}_{18}\right.$ and $\left.\mathrm{L}_{111}\right)$ and four cultivars (RGS003, Zarfam, Hyola401 and PF7045/91) were evaluated in four salinity levels of irrigation water including $0,4,8$ and 12 $\mathrm{dsm}^{-1}$ at Agriculture and Natural Resources Research Centre of Mazandran, Sari, Iran, during 2010-11. A factorial experiment based on completely randomized design (CRD) with 3 replications were considered for evaluation of 28 treatments in pot condition. The salt solution was prepared by taking $\mathrm{NaCl}: \mathrm{CaCl}_{2}$ in the ratio of $1: 1$ and the electrical conductivity of different salinity levels was adjusted by a direct reading conductivity meter. Soli analysis results are shown in Table 1. The soil belongs to the non-saline soil with a natural reaction and the amount of lime which is relatively high. Levels of nutrients, soil organic matter levels in the medium and other nutrients, including potassium, phosphorus, iron, manganese and copper are desirable. In each plot 10 seeds were grown in separate 8-liter pots and five plants were maintained for evaluating. Electrical conductivities of the saline treatments were increased to the desired levels by incremental additions of the salts over 10-day period to avoid osmotic shock to the seedlings. Plants in all pots were irrigated until saturation, with the excess solution allowed to drain into collection pans. All pots were maintained at farm condition and also they were isolated from raining. The studied traits were seed yield and ion concentrations in shoot including $\mathrm{Ca}, \mathrm{Na}, \mathrm{K}$ and $\mathrm{Cl}$ in vegetative stage( $\mathrm{V}-\mathrm{Ca}, \mathrm{V}-\mathrm{Na}$, $\mathrm{V}-\mathrm{K}$ and $\mathrm{V}-\mathrm{Cl}$, respectively) and these ions in reproductive stage (after 50 percentage of flowering in each genotype) including R-Ca, R-Na, R-K and R-Cl. For ions extractions, plant samples were ground by mill and then dried in a furnace at $500^{\circ} \mathrm{C}$ for 2 hours. After that, plant samples were added $5 \mathrm{ml}$ of $2 \mathrm{M} \mathrm{HCl}$ for digestion and then they were filtered and diluted by distilled water. The final volume of each sample was $100 \mathrm{ml}$. Amount of $\mathrm{K}$ and $\mathrm{Na}$ of each final sample was measured by flame photometer and $\mathrm{Ca}$ was measured by atomic absorption[11]. For chloride determination, $\mathrm{Cl}$ was determined by the silver ion-titration method with an automatic chloridometer (Buckhler-Cotlove chloridometer) according to Bozcuk[4]. Pearson correlation was detected for all the traits. All studied traits were analysis based on factorial experiments based on completely randomized[9].

\section{Results and Discussion}

\subsection{Analysis of variance}

Significant mean square of genotype were observed for seed yield and shoot ions in vegetative stage including $\mathrm{V}-\mathrm{Ca}$, $\mathrm{V}-\mathrm{Na}$ and $\mathrm{V}-\mathrm{Cl}$ and also shoot ions in reproductive stage including R-Ca, R-Na, R-K and R-Cl (Table 2). Significant mean square of salinity levels were observed seed yield and all shoot ions at two growth stages except R-Ca which indicating $\mathrm{Ca}$ at reproductive stage is not good indicator for recognizing the tolerant rapeseed genotypes. Significant mean square of interaction effect of genotypes $\mathrm{x}$ salinity levels were detected for seed yield and V-Cl, R-Ca, R-Na and $\mathrm{R}-\mathrm{K}$.

\subsection{Mean performances of the traits}

The interaction effect of genotypes $\times$ salinity levels means for studied traits is presented in Table 3. Due to increasing salinity levels V-Ca was increased in L14 and Zarfam but in other genotypes it was not significant affected by salinity levels increasing. Amount of $\mathrm{Ca}$ at reproductive stage (R-Ca) was significant increased in L18 by increasing of salinity levels. V-K and R-K were decreased due to increasing salinity levels. Earlier researchers[1,17,25] were reported $\mathrm{Ca}$ and $\mathrm{K}$ ameliorate the adverse effects of salinity on plants. Salinity impairs the uptake up $\mathrm{Ca}$ by plants, possibly by displacing it from the cell membrane or in some way affecting membrane function[14,20].

Table 1. Some of physicochemical properties of soil sample

\begin{tabular}{|c|c|c|c|c|c|c|c|c|c|c|c|c|c|}
\hline \multirow{2}{*}{ Class } & \multicolumn{3}{|c|}{$(\%)$} & \multicolumn{6}{|c|}{$\left(\mathrm{mg} \mathrm{Kg}^{-1}\right)$} & \multirow{2}{*}{$\begin{array}{c}\text { TNV } \\
(\%) \\
\end{array}$} & \multirow{2}{*}{$\mathrm{OC}(\%)$} & \multirow{2}{*}{ PH } & \multirow{2}{*}{$\mathrm{Ec}\left(\mathrm{dsm}^{-1}\right)$} \\
\hline & Clay & Silt & Sand & $\mathrm{Cu}$ & $\mathrm{Zn}$ & $\mathrm{Mn}$ & $\mathrm{Fe}$ & K & $\mathrm{P}$ & & & & \\
\hline Si-C-L & 28 & 56 & 16 & 3 & 0.64 & 3.1 & 9 & 352 & 9.2 & 15 & 1.41 & 7.3 & 0.68 \\
\hline
\end{tabular}

Table 2. Analysis of variance for seed yield and shoot ions compositions in rapeseed genotypes at different salinity levels

\begin{tabular}{ccccccccccc}
\hline \multirow{2}{*}{ S.O.V } & Df & V-Ca & V-Na & V-K & V-Cl & R-Ca & R-Na & R-K & R-Cl $\begin{array}{c}\text { Seed } \\
\text { yield }\end{array}$ \\
\hline Genotypes(G) & 6 & $4932^{* *}$ & $3.33^{* *}$ & 18.41 & $105.14^{* *}$ & $3080.52^{* *}$ & $15.35^{* *}$ & $286.67^{* *}$ & $712^{* *}$ & $8.29^{* *}$ \\
Salinity lev- & 3 & $196^{* *}$ & $11.01^{* *}$ & $92.68^{* *}$ & $984.72^{* *}$ & 195.51 & $365.01^{* *}$ & $385.56^{* *}$ & $6494^{* *}$ & $2.99^{* *}$ \\
els(S) & 18 & 535 & 1.39 & 7.59 & $107.88^{* *}$ & $384.25^{* *}$ & $5.95^{* *}$ & $31.16^{* *}$ & 225 & $0.57^{* *}$ \\
G x S & 18 & 102 & 0.90 & 8.77 & 32.98 & 121.27 & 2.73 & 14.34 & 176 & 0.05 \\
Error & 56 & & & & & & & &
\end{tabular}

$*$, ** Significant at $\mathrm{p}=5 \%$ and $1 \%$, respectively.

$\mathrm{V}$ : vegetative stage and $\mathrm{R}$ : reproductive stage. 
V-Na was not significant varied among the genotypes at vegetative stage and also it was not affected by increasing of salinity levels. Due to increasing of salinity levels R-Na was significant increased and in RGS003 its ranged was less than the other genotypes. Amount of $\mathrm{V}-\mathrm{Cl}$ and $\mathrm{R}-\mathrm{Cl}$ were increased in all of the genotypes in high amount of salinity levels. Seed yield of the genotypes were decreased followed by increasing of salinity levels but in $4 \mathrm{dsm}^{-1}$ it was yielded more seed yield than $0 \mathrm{dsm}^{-1}$ salinity level and it may be related to providing some of nutrient compositions at the second salinity level. Similarly, in previous studies[12,15] were reported that due to increasing of salinity levels, yield and yield associated traits were reduced.

\subsection{Correlation analysis}

Table 3. Interaction effects of genotypes $x$ salinity levels means for seed yield and Shoot ions at vegetative and reproductive stages

\begin{tabular}{|c|c|c|c|c|c|c|c|c|c|}
\hline Treatments & $\begin{array}{l}\mathrm{V}-\mathrm{Ca} \\
(\mathrm{mg} / \mathrm{gr})\end{array}$ & $\begin{array}{l}\text { V-Na } \\
(\mathrm{mg} / \mathrm{gr})\end{array}$ & $\begin{array}{c}\mathrm{V}-\mathrm{K} \\
(\mathrm{mg} / \mathrm{gr})\end{array}$ & $\begin{array}{c}\mathrm{V}-\mathrm{Cl} \\
(\mathrm{mg} / \mathrm{gr})\end{array}$ & $\begin{array}{l}\mathrm{R}-\mathrm{Ca} \\
\text { (mg/gr) }\end{array}$ & $\begin{array}{c}\mathrm{R}-\mathrm{Na} \\
(\mathrm{mg} / \mathrm{gr})\end{array}$ & $\begin{array}{c}\mathrm{R}-\mathrm{K} \\
(\mathrm{mg} / \mathrm{gr})\end{array}$ & $\begin{array}{c}\mathrm{R}-\mathrm{Cl} \\
(\mathrm{mg} / \mathrm{gr})\end{array}$ & $\begin{array}{c}\text { Seed } \\
\text { yield } \\
\text { (gr/pot) }\end{array}$ \\
\hline V1S1 & 68.94 & 5.27 & 27.12 & 31.01 & 72.31 & 3.45 & 15.73 & 47.14 & 0.89 \\
\hline V1S2 & 71.60 & 6.65 & 25.98 & 42.19 & 72.67 & 3.70 & 16.76 & 49.39 & 2.31 \\
\hline V1S3 & 65.02 & 6.93 & 25.02 & 43.49 & 62.19 & 6.46 & 14.94 & 67.19 & 0.69 \\
\hline V1S4 & 65.02 & 7.32 & 23.32 & 46.63 & 76.70 & 8.70 & 10.86 & 85.16 & 0.80 \\
\hline V2S1 & 76.13 & 5.23 & 28.19 & 26.92 & 73.79 & 0.94 & 28.39 & 30.17 & 1.16 \\
\hline V2S2 & 81.43 & 7.29 & 26.11 & 44.91 & 83.71 & 3.32 & 26.22 & 52.32 & 1.69 \\
\hline V2S3 & 134.23 & 7.89 & 26.51 & 47.16 & 62.03 & 8.32 & 21.63 & 89.85 & 0.67 \\
\hline V2S4 & 115.45 & 6.86 & 24.74 & 42.90 & 78.10 & 7.66 & 21.87 & 55.26 & 0.59 \\
\hline V3S1 & 91.78 & 5.30 & 28.93 & 27.93 & 38.26 & 0.76 & 33.20 & 47.00 & 0.30 \\
\hline V3S2 & 97.67 & 5.34 & 23.73 & 35.62 & 48.43 & 1.66 & 34.08 & 47.79 & 0.10 \\
\hline V3S3 & 89.71 & 4.98 & 21.93 & 31.06 & 37.25 & 5.60 & 21.81 & 71.06 & 0.03 \\
\hline V3S4 & 115.25 & 6.05 & 21.66 & 56.68 & 15.80 & 7.91 & 15.28 & 72.48 & 0.02 \\
\hline V4S1 & 90.77 & 4.59 & 29.01 & 28.99 & 17.77 & 0.63 & 24.86 & 23.83 & 2.52 \\
\hline V4S2 & 73.37 & 6.05 & 28.30 & 36.33 & 22.82 & 2.15 & 24.16 & 41.75 & 2.53 \\
\hline V4S3 & 62.46 & 5.76 & 22.96 & 33.85 & 43.48 & 8.17 & 20.00 & 58.79 & 2.03 \\
\hline V4S4 & 71.96 & 5.44 & 26.30 & 34.33 & 65.61 & 9.96 & 19.21 & 53.27 & 2.46 \\
\hline V5S1 & 63.58 & 4.27 & 26.16 & 23.90 & 42.80 & 1.02 & 22.12 & 22.70 & 3.08 \\
\hline V5S2 & 62.16 & 7.61 & 28.28 & 39.41 & 43.01 & 4.88 & 23.15 & 41.18 & 2.74 \\
\hline V5S3 & 55.77 & 6.29 & 26.15 & 33.61 & 43.42 & 8.51 & 19.35 & 57.64 & 2.44 \\
\hline V5S4 & 49.65 & 6.58 & 21.74 & 39.44 & 44.25 & 11.15 & 17.99 & 65.13 & 1.25 \\
\hline V6S1 & 51.72 & 5.76 & 27.94 & 33.02 & 37.07 & 1.19 & 33.39 & 23.07 & 2.30 \\
\hline V6S2 & 47.65 & 5.16 & 25.80 & 25.92 & 39.62 & 3.44 & 35.45 & 41.55 & 2.89 \\
\hline V6S3 & 57.98 & 5.94 & 23.52 & 38.46 & 47.55 & 9.23 & 20.83 & 63.49 & 1.80 \\
\hline V6S4 & 56.03 & 6.30 & 21.27 & 49.46 & 48.12 & 14.52 & 19.21 & 79.91 & 1.24 \\
\hline V7S1 & 54.07 & 4.17 & 26.31 & 23.43 & 39.94 & 1.21 & 32.14 & 23.77 & 1.60 \\
\hline V7S2 & 50.40 & 6.33 & 22.28 & 32.43 & 45.25 & 4.12 & 29.97 & 34.37 & 1.18 \\
\hline V7S3 & 60.82 & 7.08 & 24.11 & 43.31 & 49.10 & 9.91 & 26.88 & 52.51 & 0.92 \\
\hline V7S4 & 53.76 & 6.33 & 20.14 & 41.30 & 44.45 & 12.73 & 27.60 & 60.68 & 1.51 \\
\hline $\operatorname{LSD}(p=0.05)$ & 16.49 & 1.55 & 4.84 & 9.38 & 17.98 & 2.70 & 6.18 & 21.66 & 0.37 \\
\hline $\operatorname{LSD}(p=0.01)$ & 19.71 & 1.85 & 5.78 & 11.21 & 21.49 & 3.22 & 7.39 & 25.89 & 0.44 \\
\hline
\end{tabular}

V1: RGS003, V2: L14,V3: Zarfam,V4: L18, V5: Hyola401,V6: L111 and V7: Sarigol.

$\mathrm{S} 1: 0 \mathrm{ds} \mathrm{m}^{-1}, \mathrm{~S} 2: 4 \mathrm{ds} \mathrm{m}^{-1}, \mathrm{~S} 3: 8 \mathrm{ds} \mathrm{m}^{-1}$ and S4: $12 \mathrm{ds} \mathrm{m}^{-1}$.

Table 4. Correlation among seed yield and shoot ions compositions in rapeseed genotypes at different salinity levels.

\begin{tabular}{cccccccccr}
\hline Traits & V-Ca & V-Na & V-K & V-Cl & R-Ca & R-Na & R-K & R-Cl & Seed yield \\
\hline V-Ca & 1 & & & & & & & & \\
V-Na & 0.15 & 1 & & & & & & \\
V-K & 0.13 & -0.19 & 1 & & & & & \\
V-Cl & 0.33 & $0.77^{* *}$ & $-0.47^{*}$ & 1 & & & & \\
R-Ca & 0.07 & $0.41^{*}$ & 0.04 & 0.19 & 1 & & & \\
R-Na & -0.11 & $0.50^{* *}$ & $-0.71^{* *}$ & $0.64^{* *}$ & 0.13 & 1 & & 1 \\
R-K & -0.10 & -0.37 & 0.26 & $-0.54^{* *}$ & -0.28 & $-0.51^{* *}$ & 1 & $-0.61^{* *}$ & 1 \\
R-Cl & 0.31 & $0.59^{* *}$ & $-0.58^{* *}$ & $0.74^{* *}$ & 0.24 & $0.76^{* *}$ & -0.11 & $-0.52^{* *}$ & 1 \\
Seed yield & $-0.51^{* *}$ & -0.17 & $0.41^{*}$ & $-0.39^{*}$ & -0.16 & -0.18 & 0.11 & & \\
\hline
\end{tabular}

*, ** Significant at $\mathrm{p}=5 \%$ and $1 \%$, respectively.

$\mathrm{V}$ : vegetative stage and R: reproductive stage. 
In general due to increasing of salinity levels, V-Ca was increased in the genotypes which had not high seed yield in saline environment. Significant negative correlation of $\mathrm{K}$ with $\mathrm{Na}$ and $\mathrm{Cl}$ indicating the ameliorating effect of $\mathrm{K}$ on toxic effects of $\mathrm{Na}$ and $\mathrm{Cl}$. Significant positive correlation of $\mathrm{V}-\mathrm{K}$ with seed yield indicating that $\mathrm{K}$ at vegetative stage can be used as selection criterion for detecting high seed yield genotypes in saline environment. Due to adverse effect of $\mathrm{Cl}$ on seed yield, the correlation of this ion with seed yield was significant and negative at vegetative and reproductive stages.

\section{REFERENCES}

[1] Amador BM, S. Yamada, T. Yamaguchi, E.R. Puente, N.A.V. Serrano, J.L.G Hernandez, R.L. Aguilar, E.T. Dieguez and A.N. Garibay. 2007. Influence of calcium silicate on growth, physiological parameters and mineral nutrition in two legume species under salt stress. J. of Agronomy and Crop Science 193: 413-421.

[2] Ashraf, M., and T. McNeilly. 2004. Salinity tolerance in brassica oilseeds. Critical Review of Plant Science 23(2): $157-174$.

[3] Bandeh-Hagh, A., M. Toorchi, A. Mohammadi, N. Chaparzadeh , G.H. Salekdeh, and H. Kazemnia .2008. Growth and osmotic adjustment of canola genotypes in response to salinity. Journal of Food, Agriculture \& Environment. 6(2): 201-208.

[4] Bozcuk S (1970). Water and salt relations of statics species with particular reference to the problem of halophytes. Ph.D. Thesis University of Sussex, UK.

[5] Bybordi A. 2010. Effects of salinity on yield and component characters in canola (Brassica napus L.) cultivars. Notulae Scientia Biologicae 2 (1) 2010, 81-83.

[6] Das, S., M. Chandra and B. Ghosh, 1994. Response of Brassica campestris cultivars to salinity stress. Plant Physiology and Biochemistry New Delhi. 21, (2), 76-79.

[7] Francois, L. E.1994. Growth, seed yield, and oil content of canola grown under saline environments. Agronomy Journal $86,(2), 233-237$.

[8] Gorham, J. 1993. Genetics and physiology of enhanced K/Na discrimination. In Genetic Aspects of Plant Mineral Nutrition. Randall P., Ed.; Kluwer Academic Publishers, Dordrecht, The Netherlands. Pp:151-159.

[9] Gomez, K.A, and A. A. Gomez.1984. Statistical procedures for Agricultural Resarch;John Wiley and Sons, New York.

[10] He, T., and G.R. Cramer. 1992. Growth and mineral nutrition of six rapid-cycling Brassica species in response to seawater salinity. Plant Soil 139 (2), 285-294.

[11] Isaac, R. A., J.D. Kerber. 1971. Atomic absorption and flame photometry: Techniques and uses in soil, plant and water analysis. In Instrumental Methods for Analysis of Soil and
Plant Tissue. Walsh, L. M., Ed.; Soil Sci. Of Am. Madison, Wis. Pp: 17-37.

[12] Islam, M.R., M.A.R. Bhuiyan, B. Prasad and M. A. Quddus.2001. Salinity effect on yield and component characters in rapeseed and mustard varieties. Journal of biological sciences 1(9):840-842

[13] Kumar, D. 1995. Salt tolerance in oilseed brassicas-present status and future prospects. Plant Breeding Abstract 65, (10): $1439-1477$.

[14] Lauchli, A. 1990. Calcium. salinity and the plasma membrane. Current Topics in Plant Physiology4, 26-35.

[15] Mahmoodzadeh, H. 2008. Comparative study of tolerant and sensitive cultivars of Brassica napus in response to salt conditions .Asian Journal of plant Science 7(6):594-598.

[16] Minhas, P.S., D.R. Sharam, and B.K. Khosla. 1990. Effect of alleviation of salinity stress at different growth stages of Indian mustard (Brassica juncea). Indian Journal of Agriculure Sciences 60( 5): 343-346.

[17] Munns, R. 2002. Comparative physiology of salt and water stress. Plant Cell Environment 25: 239-250

[18] Porcelli, C. A., F.H. Gutierrez-Boem, and R.S. Lavado.1995. The $\mathrm{K} / \mathrm{Na}$ and $\mathrm{Ca} / \mathrm{Na}$ ratios and rapeseed yield under soil salinity or sodicity. Plant Soil 175, (2): 251-255.

[19] Puppala, N. J., L. Fowler, L. Poindexter, and H.L. Bhadwaj. 1999. Evaluation of salinity tolerance of canola germination, In Perspectives on new crops and new uses. Janick J., Ed.; ASHS press, Alexandria, VA. 251-253.

[20] Rameeh, V., A. Rezai, and G. Saeidi. 2004. Study of salinity tolerance in rapeseed. Communications in Soil Science and Plant Analysis 35: 2849-2866.

[21] Schorder, J. I., J.M. Ward, and W. Gassmann. 1994. Perspectives on the physiology and structure of inward-rectifying $\mathrm{K}$ channels in higher plants: biophysical implications for $\mathrm{K}$ uptake. Annual review of biophysics and biomolecular structure 23, 441-471.

[22] Sharma, P. C., and S.K. Gill. 1994. Salinity-induced effect on biomass, yield, yield-attributing characters and ionic contents in genotypes of Indian mustard (Brassica juncea). Indian Journal of Agriculure Sciences 64(11): 785-788.

[23] Thakral, N., H. Singh, P. Kumar, T.P. Yavada, and S.L. Mehta. 1998. Association analysis between physio-chemical parameters with seed yield in Indian mustard under normal and saline environments. Crucifereae Newsletter 20, 59-60.

[24] Tunuturk, M., R. Tuncturk, B. Yildirim and V. Ciftci. 2011. Effect of salinity stress on plant fresh weight and nutrient composition of some Canola (Brassica napus L.) cultivars. African Journal of Biotechnology. 10(10): 1827-1832.

[25] Volkamar, K. M., Y. Hu, and H. Steppuhn. 1998. Physiological responses of plants to salinity: A review. Canadian Journal of Plant Science 78, 19-27.

[26] Zamani, Z., M.T. Nezami, D. Habibi, and M.B. Khorshidi.2010. Effect of quantitative and qualitative performance of four canola cultivars (Brassica napus L.) to salinity conditions. Advances in Environmental Biology, 4(3): 422-427. 